Науковий вісник Дьвівського націонадьного університету ветеринарної медицини та біотехнодогій імені С.3. Гжицького

\author{
Scientific Messenger of Lviv National University \\ of Veterinary Medicine and Biotechnologies
}

UDC 636.5

\title{
Effect of aquacitrate of micro elements on indices of nonspecific resistance and cellular immunity in chicken broilers
}

\author{
S.M. Medvid \\ Institute of Animal Biology of NAAS, Lviv, Ukraine
}

Article info

Received 04.01.2018

Received in revised form 19.02.2018

Accepted 23.02.2018

Institute of Animal Biology of NAAS, V. Stusa Str., 38, Lviv, 79034, Ukraine.

Tel: $+38-098-266-52-53$

E-mail: a_gunchak@ukr.net
Medvid, S.M. (2018). Effect of aquacitrate of micro elements on indices of nonspecific resistance and cellular immunity in chicken broilers. Scientific Messenger of Lviv National University of Veterinary Medicine and Biotechnologies. 20(84), 33-38. doi: 10.15421/nvlvet8406

The article presents data on the influence of the complex of micro elements ( $\mathrm{Fe}, \mathrm{Cu}, \mathrm{Zn}, \mathrm{Co}, \mathrm{Mn})$ in the form of aquacitrate on the indices of non-specific and cellular immunity in chicken broilers. The poultry received a fodder, balanced by nutrients, according to its type, age and productivity. Control group of chickens were added standard mineral premix (SP) from inorganic compounds of bioelements. Broilers of experimental groups were given water with a complex mineral additive of aquacitrates. In particular, the chickens of the first experimental group - in the amount corresponding to their content in the standard premix (SP), and the $2 n d, 3 r d$, 4th and 5th experimental groups - in the amount equal to 3/4, 1/2, 1/4 and $1 / 10$ of the content of mineral elements in the standard premix. It was found that bactericidal and lysozyme activity of blood serum (BASB and LASB) were the highest in broiler chickens of the third and fourth experimental groups and exceeded the control values by 5.7 and 5.3\%, respectively. In the bird of the second and fifth groups, the studied indicators were closer to the ones in control. However, in the chickens of the group D1, giving them the highest studied dose of aquacitrate of micor elements, the values of BASB and LASB tended to decrease. Concerning the level of CIC in serum, it was the highest in the chickens of the second, third and fourth groups, the lowest in the group D1. A similar pattern is also characteristic for phagocytic activity of pseudoiesinophils (PhA). The bite of half and even the quaternary amount of citrates of micro elements, compared with the amount of bioelements in inorganic form, provided an increase, compared to control, of PhA. At such a dose of micro elements in the nanoform in the blood of broilers, the number of Ttotal and T-active lymphocytes increased, including T-heeler cells and decreased the relative number of Tsuppressors. The bird of the first experimental group was characterized by a decrease in the percentage of T-heeler against the background of a slight increase of T-suppressors. Thus, the results of studies of indices of nonspecific and cellular immunity suggest that micor elements in the nanodisperse form, due to better bioavailability and high bioactivity, have a positive effect on the formation and development of the immune system in broiler chickens at a dose corresponding to 25 and 50\%, from recommended quantity of biometals in the standard premix.

Key words: chicken broilers, microcrystalline aquatic citrate, resistance, cellular immunity.

\section{Вплив аквацитрату мікроелементів на показники неспецифічної резистентності та клітинний імунітет у курчат-бройлерів}

\author{
С.М. Медвідь
}

Інститут біології тварин НААН України, м. Львів, Україна

У статті наведено дані щодо впливу комплексу мікроелементів (Fe, Cu, Zn, Co, Mn) у формі аквацитрату на показники неспецифічної і клітинної ланки імунітету у курчат-бройлерів. Вся птиця отримувала повноцінний комбікорм, збалансований за поживними речовинами, відповідно до ї̈ виду, віку та напряму продуктивності. Курчатам контрольної групи додавали стандартний мінеральний премікс (СП) із неорганічних сполук біоелементів. Бройлерам дослідних груп випоювали з водою комплексну мінеральну добавку аквацитратів. Зокрема, курчатам першої дослідної групи - у кількості, шо відповідала їх вмісту в стандартному преміксі (СП), а 2-ї, 3-ї, 4-ї і 5-ї дослідних груп - у кількості, рівній 3/4, 1/2, 1/4 та 1/10 від вмісту мінеральних елементів в стандартному преміксі. Встановлено, що бактерищидна і лізочимна активність сироватки крові (БАСК $і$ ЛАСК) були найвищими у курчат- 
бройлерів третьої та четвертої дослідних груп і перевищувала величини контролю на 5,7 і 5,3\% відповідно. У птиці другої і п’ятої груп досліджувані показники наближалися до аналогічних в контролі. Однак у курчат групи Д 1 , за випоювання їм найвищої досліджуваної дози аквацитрату мікроелементів, величини БАСК $і$ ЛАСК мали тенденцію до зниження. Щодо рівня ЦІК в сироватиі крові, то найвищим він був у курчат другої, третьої і четвертої груп, найнижчим - у групі Д. Подібна закономірність характерна також для фагоцитарної активності псевдоеозинофілів (ФА). Випоювання птиці половинної $і$ навіть четвертинної кількості цитратів мікроелементів, порівняно з кількістю біоелементів у неорганічній формі, забезпечувало підвищення, порівняно з контролем, ФА. За такої дози мікроелементів у наноформі в крові бройлерів зростала кількість T-загальних $і$ T-активних лімфоцитів, в т.ч. Т-хелперів та знижувалась відносна кількість Т-супресорів. Для птиці першої дослідної групи характерним було зниження відсотка Т-хелперів на тлі незначного зростання Т-супресорів. Таким чином, результати досліджень показників неспецифічного $і$ клітинного імунітету свідчать, щз мікроелементи у нанодисперсній формі, за рахунок кращої біодоступності та високої біоактивності справляють свій позитивний вплив на формування і становлення імунної системи в курчат-бройлерів у дозі, шзо відповідає 25 і 50\% від рекомендованої кількості біометалів у стандартному преміксі.

Ключові слова: курчата-бройлери, аквацитрат мікроелементів, резистентність, клітинний імунітет.

\section{Вступ}

Вагомим фактором підвищення продуктивності птиці є раціональна і збалансована годівля. 3 урахуванням високої інтенсивності росту курчат-бройлерів важливе значення для них має забезпечення не лише повноцінного протеїнового живлення, а й створення відповідного мінерального балансу (Bratyshko et al., 2005; Suraj, 2009; Kyryliv et al., 2015; Ibatullin and Holubiev, 2017; Ibatullin et al., 2017).

Відомо, що окремі регіони України, і в першу чергу західний, відносяться до біогеохімічної зони 3 низьким вмістом у грунті, воді, а й відповідно у кормах рухомих форм Феруму, Цинку, Купруму, Кобальту і Мангану. При використанні у годівлі птиці кормів власного виробництва не завжди уможливлюється нормування в них мікроелементів, оскільки зернові культури, що проростають на грунтах з низьким вмістом біометалів є бідними на вкрай необхідні мікроелементи (Humeniuk et al., 2004; Hurskyi, 2006; Koltun and Kachynskyi, 2011; Hunchak et al., 2016; Medvid et al., 2017). Тому в годівлі курчат-бройлерів $є$ важливим введення до їх раціонів преміксів, що містять необхідні макро- і мікроелементи, вітаміни, ферменти, амінокислоти тощо. При цьому необхідно враховувати, що кількість мінеральних речовин у складі таких преміксів часто різниться і залежить від біодоступності окремо взятих біоелементів з різних видів кормів і кормових добавок (Boikiv et al., 2001; Zakharenko and Shevchenko, 2004; Shevchenko et al., 2014; Sobolev et al., 2017).

Успіхи квантової фізики і хімії дозволили створити в Україні багато нових високоефективних засобів на основі хімічних елементів у формі карбоксилатів (цитратів) харчових кислот, що дозволяє ефективно вирішувати проблему мікроелементного гомеостазу у тварин і птиці. На думку багатьох вчених (Borysevych et al., 2010; Kosinov and Kaplunenko, 2008), біогенні і біоцидні метали у формі нанорозмірних часточок справляють стимулювальний вплив на метаболічні процеси в організмі птиці більш виражено, ніж їх відомі молекулярні форми. Висока біодоступність і біоактивність наноміді, наноцинку, наноферуму, наномагнію і нанокобальту зумовлена, очевидно, наявністю в них корпускулярного, хвильового і квантового ефектів, які $є$ каталізаторами біохімічних реакцій і посилюють їхню асиміляційну здатність. Включення до раціонів птиці біоактивних наноаквахелатів, Феруму, Купруму, Цинку, Мангану і Кобальту забезпе- чує дію біометалів як мікроелементів, так і специфічних активних наноматеріалів. При цьому автори відзначають, що досліджувані речовини у формі нанорозмірних частинок сприяють зростанню у бройлерів середньодобових приростів маси тіла та зменшують загибель курчат (Skal'nij, 2004; Voloshyna et al., 2008).

За позитивної оцінки інформації щодо можливого використання у складі преміксів для птиці карбоксилованих чи цитратованих форм мікроелементів важливим залишається встановлення механізму дії та оптимальних кількостей біоелементів у такій формі для забезпечення метаболічних процесів на рівні генетичних можливостей.

На нашу думку, актуальним є вивчення впливу мікроелементів у наноформі на формування резистентності організму птиці до інфекції. Метою роботи було 3'ясування впливу аквацитрату мікроелементів (Fe, $\mathrm{Mn}, \mathrm{Co}, \mathrm{Zn}, \mathrm{Cu})$ у різних кількостях на стан імунної системи курчат-бройлерів.

\section{Матеріал і методи досліджень}

Дослід проведено на шести групах (по 15 голів у кожній) курчат-бройлерів кросу РОСС-308, починаючи $з$ 10-добового віку. Утримання і годівля птиці відповідала технологічним вимогам. Вся птиця одержувала повнораціонний комбікорм (ПРК), збалансований за поживними і біологічно активними речовинами (табл. 1).

Курчатам дослідних груп випоювали з водою мінеральний комплекс за схемою, наведеною в таблиці 2.

У кінці досліду (42-а доба), що збігався із закінченням вирощування птиці, проведено забій курчатбройлерів і відібрано кров для імунологічних досліджень.

У крові курчат-бройлерів визначали відсотковий вміст Т- і В-лімфоцитів та окремих їхніх популяцій у реакції спонтанного розеткоутворення $з$ еритроцитами барана за методикою, описаною В.М. Митюшниковим (1985). Принцип методу грунтується на характерній особливості Т-лімфоцитів, а саме наявності на поверхні специфічних рецепторів до еритроцитів барана, що дозволяє проводити їх диференціальну діагностику i підраховувати відносну кількість. За кількістю мікроцитів, адсорбованих одним еритроцитом, роблять висновок про ступінь активності Тклітин. Щодо відносної кількості В-лімфоцитів - їхню ідентифікацію проводили за наявністю у них мембранних імуноглобулінових рецепторів, що забезпе- 
чують приєднання до В-лімфоцитів індикаторних клітин, які на своїй поверхні містять комплементантиген-комплекс (ЕАС-РУЛ). Як індикаторні клітини теж були використані еритроцити барана, сенсибілізовані комплементом та антитілами. Визначення відносної кількості теофілінрезистентних лімфоцитів (Т-хелпери) грунтується на тому, що ці клітини несуть на своїй поверхні рецептори до імуноглобулінів класу М та Т-супресори - до імуноглобулінів класу G. Хелперні лімфоцити здатні формувати розетки після їх інкубації теофіліном (теофілінрезистентні клітини). Кількість теофілінчутливих лімфоцитів (Т-супресори) визначається за різницею між кількістю Т-РУЛ та Тхелперів.

\section{Таблиця 1}

Склад повнораціонного комбікорму для курчат-бройлерів

\begin{tabular}{|c|c|c|c|}
\hline \multirow{2}{*}{ Інгредієнти } & \multicolumn{3}{|c|}{ Вміст, \% } \\
\hline & 0-14 діб & 14-28 діб & від 28 діб \\
\hline Кукурудза & 36,50 & 37,00 & 35,00 \\
\hline Пшениця & 22,30 & 20,00 & 22,50 \\
\hline Шрот соняшниковий & - & 9,00 & 15,00 \\
\hline Шрот соєвий, 44 & 34,50 & 26,50 & 18,50 \\
\hline Олія & 2,00 & 3,30 & 4,10 \\
\hline Крейда & 1,60 & 1,60 & 1,60 \\
\hline Сіль & 0,30 & 0,30 & 0,30 \\
\hline Монокальційфосфат & 1,30 & 1,30 & 1,30 \\
\hline Премікс & 1,50 & 1,50 & 1,50 \\
\hline Разом & 100 & 100 & 100 \\
\hline \multicolumn{4}{|c|}{ У 100 грамах комбікорму міститься, \%: } \\
\hline Обмінної енергії, ккал & 290,00 & 300,00 & 305,00 \\
\hline Сирого протеїну & 22,09 & 21,38 & 20,02 \\
\hline Сирого жиру & 4,34 & 5,64 & 6,41 \\
\hline Сирої клітковини & 3,82 & 4,44 & 4,80 \\
\hline Кальцію & 0,90 & 0,90 & 0,88 \\
\hline Фосфору & 0,68 & 0,71 & 0,71 \\
\hline Натрію & 0,15 & 0,15 & 0,15 \\
\hline Лізину & 1,31 & 1,20 & 1,05 \\
\hline Метіоніну+цистину & 0,96 & 0,87 & 0,82 \\
\hline
\end{tabular}

\section{Таблиця 2}

Схема досліду

\begin{tabular}{|c|c|}
\hline Групи & Характер живлення \\
\hline Контрольна (К) & ПРК+СП (стандартний премікс) \\
\hline 1 дослідна (Д $)$ & $\begin{array}{l}\text { ПРК+випоювання комплексу мінеральних речовин у формі аквацитрату (кількість біоелементів } \\
\text { аналогічна кількості у СП) }\end{array}$ \\
\hline 2 дослідна (Д2) & $\begin{array}{l}\text { ПРК+випоювання комплексу мінеральних речовин у формі аквацитрату (кількість біоелементів - } \\
3 / 4 \text { від кількості у СП) }\end{array}$ \\
\hline 3 дослідна (Д) & $\begin{array}{l}\text { ПРК+випоювання комплексу мінеральних речовин у формі аквацитрату (кількість біоелементів-- } \\
1 / 2 \text { від кількості у СП) }\end{array}$ \\
\hline 4 дослідна (Д $)$ & $\begin{array}{l}\text { ПРК+випоювання комплексу мінеральних речовин у формі аквацитрату (кількість біоелементів - } \\
\text { 1/4 від кількості у СП) }\end{array}$ \\
\hline 5 дослідна (Д) & $\begin{array}{l}\text { ПРК+випоювання комплексу мінеральних речовин у формі аквацитрату (кількість біоелементів - } \\
\text { 1/10 від кількості у СП) }\end{array}$ \\
\hline
\end{tabular}

У сироватці крові курчат-бройлерів нефелометрично досліджували бактерицидну активність сироватки крові (БАСК) за методикою Ю.М. Маркова (1968). Як тест-культуру використали культуру Echerichia coli. Лізоцимну активність сироватки крові (ЛАСК) досліджували теж фотонефелометрично з використанням мікробної культури Micrococcus lisodecticus (Дорофейчук В.Г, 1986). Визначення фагоцитарної активності псевдоеозинофілів (ФА) проводили за методикою Гостєва (1987). Як тест-культуру було використано Staphilococcus aureus. Інтенсивність фагоцитозу визначали за фагоцитарним індексом (ФI) і фагоцитар- ним числом (ФЧ). Циркулюючі імунні комплекси досліджували за методикою Е.Ф. Чернушенко (1981).

\section{Результати та їх обговорення}

У результаті проведених нами досліджень встановлено, що випоювання курчатам-бройлерам наноцитрату мікроелементів позитивно впливає на стан їхньої гуморальної і клітинної ланки імунітету і є дозозалежним від поступлення мікроелементів в організм.

За оцінкою сироватки крові курчат дослідних груп з'ясовано, що БАСК і ЛАСК була найвищою у брой- 
лерів 3-ї і 4-ї груп або в птиці, що отримувала половинну і четвертинну частку від кількості мікроелементів у стандартному преміксі (СП). Порівняно із показниками курчат-бройлерів контрольної групи досліджувані величини були на 5,7 і 5,3\% вищими. За випоювання птиці цитратованих мікроелементів у кількості, що відповідала 75\% вмісту біоелементів у СП (група Д2), нами відзначено, що показники БАСК і ЛАСК були близькими до аналогічних в контролі. Очевидно, що застосування аквацитрату мікроелементів у більш високій дозі (група Д 1 ) є невиправданим 3 економічної точки зору і небажаним - 3 технологіч- ної і екологічної. Отримані результати досліджень сироватки крові курчат-бройлерів цієї дослідної групи відображають вірогідне зниження БАСК на 9,1\% $(\mathrm{P}<0,05)$ і ЛАСК - на 9,3\% (P < 0,05) відповідно відносно контролю. За випоювання птиці найнижчої досліджуваної кількості аквацитратів (група Д $)$ показники їхньої неспецифічної резистентності, порівняно 3 контролем, тенденційно знижувались, хоч і не виходили за межі фізіологічних величин. Циркулюючі імунні комплекси (ЦІК), будучи інтегральним показником гуморальної ланки імунної відповіді, реалізують фізіологічні процеси гомеостазу.

\section{Таблиця 3}

Вплив аквацитрату мікроелементів на показники неспецифічної резистентності у курчат-бройлерів, $\mathrm{M} \pm \mathrm{m}, \mathrm{n}=15$

\begin{tabular}{ccccccc}
\hline \multirow{2}{*}{ Група } & \multicolumn{7}{c}{ Показники } \\
\cline { 2 - 7 } & $\begin{array}{c}\text { БАСК, } \\
\%\end{array}$ & $\begin{array}{c}\text { ЛАСК, } \\
\%\end{array}$ & $\begin{array}{c}\text { ЦІК, } \\
\text { од/100мл }\end{array}$ & $\begin{array}{c}\text { ФА, } \\
\%\end{array}$ & $\begin{array}{c}\text { ФІ, } \\
\%\end{array}$ & $\begin{array}{c}\text { ФЧ, } \\
\text { мк/кл. }\end{array}$ \\
\hline К & $49,32 \pm 1,82$ & $22,90 \pm 0,86$ & $15,40 \pm 0,62$ & $33,16 \pm 1,90$ & $8,64 \pm 0,32$ & $2,18 \pm 0,14$ \\
Д $_{1}$ & $44,88 \pm 0,88^{*}$ & $20,77 \pm 1,66^{*}$ & $14,30 \pm 0,82$ & $32,18 \pm 2,66$ & $7,02 \pm 0,40$ & $1,92 \pm 0,28$ \\
Д $_{2}$ & $48,84 \pm 1,64$ & $23,12 \pm 2,06$ & $15,48 \pm 1,12$ & $33,88 \pm 3,12$ & $8,42 \pm 0,28$ & $2,16 \pm 0,16$ \\
Д $_{3}$ & $52,13 \pm 2,16$ & $24,10 \pm 2,35$ & $15,82 \pm 1,26$ & $34,60 \pm 2,90$ & $8,80 \pm 0,44$ & $2,20 \pm 0,28$ \\
Д $_{4}$ & $51,90 \pm 2,08$ & $23,80 \pm 1,82$ & $15,66 \pm 1,08$ & $34,16 \pm 2,74$ & $8,80 \pm 0,38$ & $2,16 \pm 0,24$ \\
Д $_{5}$ & $47,68 \pm 3,14$ & $22,64 \pm 2,14$ & $15,18 \pm 1,70$ & $33,44 \pm 2,02$ & $8,32 \pm 0,52$ & $2,14 \pm 0,34$ \\
\hline
\end{tabular}

Примітка: *-P $<0,05$

За введення до раціонів птиці комплексу мікроелементів (Fe, $\mathrm{Zn}, \mathrm{Co}, \mathrm{Cu}, \mathrm{Mn})$ у формі аквацитрату вміст ЦІК був найвищим, порівняно $з$ контролем, у сироватці крові курчат-бройлерів другої, третьої і четвертої груп і найнижчим - у групі Д 1 , хоч загалом досліджуваний показник перебував на відносно стабільному рівні й у межах величин, характерних для птиці на завершальному етапі вирощування. Виявлені закономірності щодо зниження напруженості неспецифічного імунітету, на тлі застосування високих доз аквацитрату мікроелементів, $\epsilon$, ймовірно, результатом пригнічення активності кишкової мікрофлори, у відповідь на що організм птиці зменшує продукцію факторів захисту неспецифічного характеру.

Заслуговують також на увагу наукові повідомлення, що зростання гуморальних факторів неспецифічної резистентності птиці, на тлі застосовування нових форм мікроелементів, є результатом відповіді організму на стимулювання росту кишкової мікрофлори, що супроводжується напруженням гострофазних білків бактерицидних систем. При цьому не можна виключати, що досліджувані біометали сприяють метаболічній активності грампозитивної анаеробної кишкової мікрофлори, стимулюючи іiі ріст і розвиток. Фізіологічна транзиторна бактеріємія, що виникає за таких умов, викликає підвищення імунологічної напруженості організму птиці.

Підтвердженням даного припущення є отримані нами результати щодо зниження фагоцитарної актив- ності псевдоеозинофілів (ФА) у крові курчат першої дослідної групи (табл. 3). За випоювання птиці половинної і навіть четвертинної кількості цитратів мікроелементів (група Д $і$ і Д4), порівняно з курчатами, що отримували біометали в неорганічній формі (К), характерною була тенденція до підвищення фагоцитозу. На тлі незначного зростання ФА вищими були у курчат цієї групи також фагоцитарне число (ФЧ) і фагоцитарний індекс (ФІ).

3 урахуванням високої біодоступності та біоактивності наноформи комплексу біметалів у наноформі, нами відзначено їхній позитивний вплив на формування клітинної ланки імунітету у птиці (табл. 4).

Рівень Т-загальних (Е-РУК) лімфоцитів у крові курчат-бройлерів дослідних груп Д ${ }_{3}$, 4 і Д 5 був близьким до аналогічних показників курчат контрольної групи. У крові курчат другої дослідної групи відносна кількість Т-лімфоцитів була дещо нижчою. При цьому відсоток Т-активних лімфоцитів (Е-РУК) найнижчим був у курчат, що отримували з водою аквацитрати у максимальній (Д, i мінімальній (Д $)$ досліджуваних дозах. Цікавою, з огляду забезпечення потреби організму птиці в мікроелементах для відповідного імуногенезу, є виявлена нами динаміка щодо зміни в крові рівня Т-теофілінчутливих (Т-РУК) або, як їх ще називають, Т-супресорів та Ттеофілінрезистентних (Т-РУК) лімфоцитів (Тхелперів). 


\section{Таблищя 4}

Відносний вміст Т- і В-лімфоцитів у крові курчат-бройлерів за надходження різних кількостей аквацитрату мікроелементів, $\mathrm{M} \pm \mathrm{m}, \mathrm{n}=15$

\begin{tabular}{|c|c|c|c|c|c|}
\hline \multirow[b]{3}{*}{ Група } & \multicolumn{5}{|c|}{ Показники } \\
\hline & \multicolumn{4}{|c|}{ Т-лімфоцити } & \multirow{2}{*}{$\begin{array}{c}\text { В-лімфоцити } \\
\text { ЕАС-РУК, } \\
\%\end{array}$} \\
\hline & $\begin{array}{l}\text { Т-загальні, } \\
\text { Е-РУК, \% }\end{array}$ & $\begin{array}{l}\text { Т-активні, } \\
\text { Е-РУК, \% }\end{array}$ & $\begin{array}{c}\text { Т-теофілін } \\
\text { чутливі, } \\
\text { Т-РУК, \% } \\
\end{array}$ & $\begin{array}{c}\text { Т-теофілін } \\
\text { резистентні, } \\
\text { Т-РУК, \% } \\
\end{array}$ & \\
\hline $\mathrm{K}$ & $72,06 \pm 3,86$ & $49,27 \pm 1,92$ & $20,88 \pm 0,88$ & $40,12 \pm 2,84$ & $21,16 \pm 1,16$ \\
\hline$Д_{1}$ & $71,90 \pm 0,85$ & $48,66 \pm 2,88$ & $21,46 \pm 2,16^{*}$ & $38,16 \pm 2,66^{*}$ & $20,06 \pm 1,88$ \\
\hline$Д_{2}$ & $71,80 \pm 1,65$ & $49,44 \pm 3,16$ & $18,26 \pm 0,90^{*}$ & $42,17 \pm 1,40$ & $20,90 \pm 2,06$ \\
\hline$Д_{3}$ & $72,16 \pm 2,12$ & $49,58 \pm 1,94$ & $18,02 \pm 1,62 *$ & $42,88 \pm 2,20$ & $22,82 \pm 1,65$ \\
\hline$Д_{4}$ & $72,96 \pm 2,54$ & $49,34 \pm 1,58$ & $18,22 \pm 2,88^{*}$ & $42,65 \pm 2,85$ & $22,40 \pm 1,40$ \\
\hline Д$_{5}$ & $72,46 \pm 3,78$ & $48,88 \pm 3,88$ & $19,60 \pm 1,16$ & $39,88 \pm 3,17$ & $20,64 \pm 1,20$ \\
\hline
\end{tabular}

Очевидно, що навіть зменшена кількість введених до раціону птиці мікроелементів, за рахунок використання високодоступної нової нанотехнологічної їх форми є достатньою для формування і становлення клітинної ланки імунітету. Відносна кількість Тхелперів у крові курчат-бройлерів другої, третьої і четвертої груп перевищувала показники контрольної групи на 5,1, 6,9 і 6,3\%, відповідно. При цьому вміст у крові курчат цих груп Т-хелперів був на 12,5, 13,7 i $12,7 \%$ нижчим. За аналізом показників клітинної ланки імунітету - у курчат-бройлерів першої дослідної групи з'ясовано, що відносна кількість у крові Тхелперів знижувалась на 4,9\%, порівняно 3 контролем, на тлі незначного зростання Т-супресорів. Більш високий рівень у крові В-лімфацитів (ЕАС-РУК), що відзначений нами у курчат 3-ї і 4-ї досліджуваних груп, $\epsilon$, на нашу думку, результатом позитивного впливу наноаквахелатів металів на механізми становлення клітинної ланки імунітету у птиці.

\section{Висновки}

Мікроелементи (Fe, $\mathrm{Zn}, \mathrm{Co}, \mathrm{Cu}, \mathrm{Mn})$ у наноцитратній формі, за рахунок кращої біодоступності та біоактивності справляють свій позитивний вплив на формування і становлення факторів неспецифічної резистентності та клітинний імунітет в курчат-бройлерів у дозі, що відповідає 25-50\% від обгрунтованої кількості біоелементів у стандартному мінеральному премікci.

\section{References}

Boikiv, D.P., Svystun, Yu.D., \& Fartushok, N.F. (2001). Mikroelementy: dosiahnennia i perspektyvy. Eksperymentalna ta klinichna fiziolohiia i biokhimiia. 2(4), 124-127 (in Ukrainian).

Borysevych, V.B., Kaplunenko, V.H., \& Kosinov, M.V. (2010). Pozytyvni i nehatyvni nanotekhnolohii. Nanomaterialy v biotekhnolohii. Osnovy nanoveterynarii: posibnyk. K.: VD «Avitsena» (in Ukrainian).

Bratyshko, N.I., Horobets, A.I., \& Prytulenko, O.V. (2005). Rekomendatsii z normuvannia hodivli silskohospodarskoi ptytsi. Birky (in Ukrainian).
Humeniuk, H.B., Kuzhda, I.I., \& Hufrii, D.F. (2004). Zabrudnennia biosfery vazhkymy metalamy ta yikh vplyv na zhyvi orhanizmy. Silske hospodarstvo. 9-10, 2-3 (in Ukrainian).

Hunchak, A.V., Ratych, I.B., Gutyj, B.V., \& Paskevych, H.A. (2016). Metabolic effects of iodine in poultry for its deficiency or excess in the diet. Scientific Messenger LNUVMBT named after S.Z. Gzhytskyj. 18, 2(67), 70-76. doi: 10.15421/nvlvet6716

Hurskyi, R. (2006). Mikroelementozna nedostatnist u zakhidnykh bioheokhimichnykh provintsiiakh IvanoFrankivskoi oblasti ta metody yii korektsii. Veterynarna medytsyna Ukrainy. 3, 36-38 (in Ukrainian).

Ibatullin, I.I., \& Holubiev, M.I. (2017). Effect of feeds containing different sources of manganese on certain carcass parameters of quail. Scientific Messenger of Lviv National University of Veterinary Medicine and Biotechnologies. 19(79), 13-16. doi: $10.15421 /$ nvlvet7903

Ibatullin, I.I., Ilchuk, I.I., \& Kryvenok, M.Ya. (2017). Digestibility of nutrients and nitrogen balance in chicken breeder meat direction of productivity at different levels of lysine in the fodder. Scientific Messenger of Lviv National University of Veterinary Medicine and Biotechnologies. 19(74), 7-11. doi: 10.15421/nvlvet7402

Koltun, Ye.M., \& Kachynskyi, Yu.M. (2011). Profilaktyka i diahnostyka mikroelementoziv Tsynku, Yodu u kurchat-broileriv. Naukovyi visnyk LNUVMBT im. S.Z. Hzhytskoho. 13, 4(50), 92-99 (in Ukrainian).

Kosinov, M.V., \& Kaplunenko, V.H. (2008). Patent Ukrainy na korysnu model №35582. Sposib otrymannia hidratovanykh i karbotyrovanykh nanochastynok «Elektroimpulsna nanotekhnolohiia otrymannia hidratovanykh i karbotovanykh nanochastynok». Opubl. 26.09.2008, biol. №18 (in Ukrainian).

Kyryliv, Ya.I., Nodzhak, M.M., \& Barylo, B.S. (2015). Efektyvnist vykorystannia vitaminiv ta mikroelementiv u hodivli kurchat-broileriv. Naukovyi visnyk LNUVMBT im. S.Z. Hzhytskoho. 17(61), 85-90 (in Ukrainian).

Medvid, S.M., Hunchak, A.V., Gutyj, B.V., \& Ratych, I.B. (2017). Prospects of rational security chickenbroilers with mineral substances. Scientific Messenger 
of Lviv National University of Veterinary Medicine and Biotechnologies. 19(79), 127-134. doi: $10.15421 /$ nvlvet7925

Shevchenko, L.V., Mykhalska, V.M., \& Maliuha, L.V. (2014). Kompleksni spoluky mikroelementiv suchasni zasoby profilaktyky khvorob ptytsi. Bioresursy i pryrodokorystuvannia. 6(1-2), 67-70 (in Ukrainian).

Skal'nij, A.V. (2004). Biojelementy v medicine. M.: Izdatel'nij dom «ONIKS 21 vek»; Mir (in Russian).

Sobolev, O.I., Gutyj, B.V., Petryshak, O.J., Golodjuk, I.P., Petryshak, R.A., \& Naumjuk, O.S. (2017). Morfologichni ta biohimichni pokaznyky krovi kachenjat, shho vyroshhujut'sja na m'jaso, za riznogo rivnja selenu $\mathrm{v}$ kombikormah. Naukovyj visnyk LNUVMBT imeni S.Z. G'zhyc'kogo. 19(74), 57-62 (in Ukrainian). doi: 10.15421/nvlvet7413

Sobolev, A., Gutyj, B., Grynevych, N., Bilkevych, V., \& Mashkin, Y. (2017). Enrichment of meat products with selenium by its introduction to mixed feed compounds for birds. Regulatory Mechanisms in Biosystems. 8(3), 417-422. doi: 10.15421/021764

Suraj, P. (2009). Kormlenie vysokoproduktivnyh krossov mjasnoj i jaichnoj pticy: sovremennye problemy i reshenija. Aktual'nye problemy sovremennogo pticevodstva. Har'kov, 273-280 (in Russian).

Voloshyna, N.O., Petrenko, O.F., Kaplunenko, V.H., \& Kosinov, M.V. (2008). Perspektyvni zastosuvannia nanochastynok metaliv u veterynarnii medytsyni. Veterynarna medytsyna Ukrainy. 9, 32-34 (in Ukrainian).

Zakharenko, M., \& Shevchenko, L. (2004). Rol mikroelementiv u zhyttiediialnosti tvaryn. Veterynarna medytsyna Ukrainy. 2, 13-15 (in Ukrainian). 